\title{
Congenital Digestive System Disorder
}

National Cancer Institute

\section{Source}

National Cancer Institute. Congenital Digestive System Disorder. NCI Thesaurus. Code C97171.

An abnormality of the digestive system that is present at birth or detected in the neonatal period. 